\title{
Adoption of environmental practices on construction sites
}

Adoção de práticas ambientais em canteiros de obra

\author{
Natasha llse Rothbucher Thomas \\ Dayana Bastos Costa
}

\begin{abstract}
ustainability on construction sites and its impacts on the environment have become increasingly relevant. Large quantities of materials, water and energy, among other resources of various types and origins, are consumed on construction sites during the production activities and by the temporary facilities. This paper aims at presenting a set of criteria for the adoption of sustainable management practices on construction sites aiming at mitigating environmental impacts produced during the construction phase. An indepth case study was carried out on the new building of the Construction Chamber for the state of Bahia, Brazil. Different environmental impacts for each construction activity specific to the construction site were studied and an economic feasibility study of each solution was performed, followed by the implementation of these practices. Monitoring data was collected through checklists, indicators and periodic project management meetings. Participant observation and document analysis were also used as sources of evidence. The main findings refer to the identification of solutions, main difficulties in adopting such solutions, the development of indicators for monitoring low environmental impact on construction sites, as well as a set of recommendations for the deployment of sustainable practices on construction sites.

Keywords: Sustainability. Construction site. Environmental practices. Management.

\section{Resumo}

Natasha Ilse Rothbucher

Thomas

De Montfort University Leicester - United Kingdom

Dayana Bastos Costa Departamento de Construção e Universidade Federal da Bahia Salvador - BA - Brasil

Recebido em 13/05/17

Aceito em 30/06/17

A sustentabilidade nos canteiros de obra e seus impactos no meio ambiente vêm se tornando bastante relevantes. Grande quantidade de materiais, água e energia, entre outros recursos de diversos tipos e origens, é consumida durante a execução das atividades de construção, o que inclui as instalações provisórias. Este artigo visa apresentar um conjunto de critérios para a adoção de práticas gerenciais sustentáveis em canteiros de obra visando à mitigação de impactos ambientais produzidos durante a fase de execução. O estudo de caso foi realizado na nova sede do Sindicato da Indústria da Construção Civil da Bahia, Brasil. Foram estudados diferentes impactos ambientais para cada atividade de construção do canteiro estudado, bem como se realizou uma análise de viabilidade para cada solução, seguida da implementação das práticas. Foram coletados dados relativos ao monitoramento da implementação das práticas por meio de listas de verificação, indicadores e reuniões periódicas com os gestores. As principais fontes de evidência foram observação participante e análise de documentos. Os principais resultados encontrados estão relacionados à identificação das soluções, às principais dificuldades na adoção dessas soluções, ao desenvolvimento de indicadores para monitoramento nos canteiros e a um conjunto de recomendações para a adoção de práticas sustentáveis nos canteiros de obra.

Palavras-chave: Sustentabilidade. Canteiro de obra. Práticas ambientais. Gestão.
\end{abstract}




\section{Introduction}

On a global scale, the construction industry is responsible for about $50 \%$ of $\mathrm{CO}_{2}$ emitted into the atmosphere, $20-50 \%$ of all natural resources consumed and $50 \%$ of all solid waste produced, some of which occurs during the construction phase of the building's life cycle, causing many environmental impacts (PULASKI, 2004; KHASREEN; BANFILL; MENZIES, 2009; PROBERT et al., 2010). The growth of the construction industry and its subsequent environmental impacts highlight the importance of the need for sustainable construction processes and actual ways to manage measures of sustainability (TAM et al., 2006; DING, 2008). Greater recognition within the architecture-engineeringconstruction (AEC) industry of the increase opportunity to influence the sustainability of project outcomes could lead to significant sustainability improvements in the AEC industry (HOLLOWAY; PARRISH, 2015).

The construction process itself causes different environmental impacts (KILBERT, 2005, UNITED..., 2006, GANGOLELLS et al., 2011, ABDUL-RAHMAN et al., 2016). Bulk materials, water and electricity among other resources of various types and origins are consumed on construction sites during the different production activities and by the temporary facilities. These activities generate solid waste and particle emissions causing a concern with soil contamination, air and water pollution and soil erosion (GANGOLELLS et al., 2014). Noise emission is also an important issue, as the construction site activities temporarily increase noise pollution, and are often set in the urban environment (BALLESTEROS et al., 2010).

Therefore, the environmental impact of construction has become of high relevance. However, the identification and monitoring of these environmental impacts have to date received little attention. It is very important to predict what the environmental impacts of construction are and identify how they can be prevented before starting an activity (IRIZARRY et al., 2012). Furthermore, many of the impacts can be controlled and mitigated by the project management team during the design and pre-construction of a building (KILBERT, 2005) thus improving the sustainability of the construction phase of a building.
However, there is a lack of knowledge on the available solutions, technologies and procedures involved with the employment of sustainable practices on construction sites (GANGOLLES et al., 2009). It is necessary to know the legislations, resources and minimum conditions required to deploy solutions after performing a technical and economic feasibility study based on the particularities of the construction site, specific production activities, logistics, financial constraints and human resources. In addition, there is a need to develop tools for measuring and monitoring the implementation of sustainable practices on site during the execution phase.

The objective of this paper is to develop a set of criteria for the adoption of environmental practices and assessing sustainable construction site aimed at mitigating the environmental impacts produced during the construction process. This study is based on an in-depth case study on the New Headquarters of the Construction Chamber for the state of Bahia (Sinduscon-BA), Brazil. In order to propose these criteria, information was obtained from a literature review on the guidelines suggested by the environmental assessment methods and from a previous work (GUIMARÃES, 2013; THOMAS; COSTA; GUIMARÃES, 2013), which aimed to identify priority needs for sustainable solutions for construction site developments.

\section{Environmental practices in construction sites}

The different environmental assessment methods for sustainable buildings present a series of good practice guidelines to be applied during the construction phase. Table 1 presents the contribution from BREEAM (Building Research Establishment Environmental Assessment Methodology (2009)), LEED (Leadership in Energy and Environmental Design (UNITED..., 2009)), AQUA-HQE process, an environmental assessment method derived from the French Haute Qualité Environnementale (HQE) method adapted by the Alberto Vanzolini Foundation for Brazil (FUNDAÇÃO..., 2010), and Selo Casa Azul, which was developed by the Brazilian Government owned bank, the CAIXA Econômica Federal, being a social-environmental classification instrument used for residential building projects (JOHN; PRADO, 2010). 
Table 1 - Contributions towards sustainable construction sites by EAM

\begin{tabular}{l|l|c|c|c|c}
\hline \multirow{2}{*}{ Generic Topics } & \multirow{2}{*}{ Environmental Aspects } & \multicolumn{3}{|c}{ Environmental Assessment Methods (EAM) } \\
\cline { 3 - 6 } & & $\begin{array}{c}\text { AQUA } \\
\text { Process }\end{array}$ & BREEAM & LEED & $\begin{array}{c}\text { SELO CASA } \\
\text { AZUL }\end{array}$ \\
\hline \multirow{3}{*}{ Resource Consumption } & Material Resources & $\mathrm{X}$ & $\mathrm{X}$ & $\mathrm{X}$ & $\mathrm{X}$ \\
& Energy Efficiency & $\mathrm{X}$ & $\mathrm{X}$ & & \\
& Water Management & $\mathrm{X}$ & $\mathrm{X}$ & $\mathrm{X}$ & $\mathrm{X}$ \\
\hline \multirow{3}{*}{ Emissions and Solid Waste } & Waste & $\mathrm{X}$ & $\mathrm{X}$ & $\mathrm{X}$ & $\mathrm{X}$ \\
& Air Pollution & $\mathrm{X}$ & $\mathrm{X}$ & $\mathrm{X}$ & \\
& Water and Soil Pollution & $\mathrm{X}$ & $\mathrm{X}$ & $\mathrm{X}$ & $\mathrm{X}$ \\
\hline \multirow{2}{*}{ Interface with External } & Urban/Environment Quality & $\mathrm{X}$ & $\mathrm{X}$ & $\mathrm{X}$ & \\
Environment & Noise Pollution & $\mathrm{X}$ & $\mathrm{X}$ & $\mathrm{X}$ & \\
\hline \multirow{2}{*}{ Intrinsic Quality of the } & Visual Pollution & $\mathrm{X}$ & $\mathrm{X}$ & $\mathrm{X}$ & \\
Construction Site & Health and Safety & $\mathrm{X}$ & $\mathrm{X}$ & $\mathrm{X}$ & \\
& Temporary Installations & & $\mathrm{X}$ & $\mathrm{X}$ & $\mathrm{X}$ \\
\hline
\end{tabular}

Source: Thomas, Costa and Guimarães (2013).

Although all assessment methods show differences within their methods of criteria evaluation and their categories, it can be seen that all criteria fall under similar themes, forming a flow system related to inputs and outputs (consumptions and emissions) within the physical, biotic and anthropic context of the construction enterprise, and its relationship with the external and internal environment, according to Degani's (2003) classification. Therefore, the discussion on sustainable construction sites will be focused on the following four elements: Resource Consumption, Emissions and Solid Waste, Interface with External Environment and Intrinsic Quality of the Construction Site. By adopting good practices, many of the environmental aspects and their associated impacts can be reduced or almost completely mitigated.

The environmental aspects related to resource consumption involve material resources, energy efficiency and waste management. Those aspects related to resource consumption can be reduced through rational resource use, coordinated and modular design principles and adopting practices that reduce material losses and selecting materials, products and construction systems with low environmental impacts and low embodied energy considering its whole life cycle process (BERGE, 2009). The generation of waste products during the different site production activities can be reduced through adequate planning and management. The waste can potentially be valorized as a raw material or energy source (RAO; JHA; MISRA, 2007; GANGOLELLS et al., 2014).

Waste, air pollution, and water and soil pollution are environmental aspects related to Emissions and Waste. Best practices and technologies, aimed at controlling particle emissions during the different construction site activities, can be adopted to minimize risks from air pollution on the occupational health of site workers and the neighborhood (KUKADIA; UPTON; HALL, 2003, UNITED..., 2006; COUNCIL..., 2010; ARAÚJO; COSTA; MORAES, 2014). Wastewater produced during site activities can also cause groundwater contamination and natural watercourse pollution, and therefore requires wastewater management plans that control infiltration and surface run-off (KIM et al., 2005; NETREGS..., 2012). Best practices are therefore required to minimize such risks (PULASKI, 2004).

The interface with external environment is another important aspect and may involve urban and environmental quality, noise pollution and visual pollution. The distress and annoyances, resulting from site traffic and machinery arising directly or indirectly from the production activities, cause visual and noise pollution (GEHLEN, 2008). Abdul-Rahman et al. (2016) recommends that possible visual and noise pollution from the construction project and the effects on the local climate should be investigated.

It is also important to control the intrinsic quality of the construction site, such as health and safety, temporary installations and innovation. The impacts caused on the health, safety and welfare of site workers should be controlled (HINZE; GODFREY; SULLIVAN, 2013; GANGOLELLS et al., 2013) and must also be considered by installing appropriate collective and individual protections during the different activities (PULASKI, 2004). Improvements on the internal air quality, comfort and environmental performance of temporary facilities may also be required (ARAÚJO, 2009). In addition, innovative technologies can provide significant improvements 
on the performance of site equipment and temporary facilities.

Based on an online survey responded by 66 highlevel professionals from development and construction companies from four metropolitan regions of Brazil, reported by Guimarães (2013) and Thomas, Costa e Guimarães (2013), a set of priorities was established and categorized in four elements: Resource Consumption, Emissions and Solid Waste, Interface with External Environment, and Intrinsic Quality of the Construction Site. Those authors classified as research priorities the technology solutions and practices considered important and very important (I \& VI), as well as the practices (PA) less applied by the respondents (see Table 2).

According to Thomas, Costa e Guimarães (2013), the technological solutions and practice needs identified in Table 2 can help governments, research academies, entity classes and private industries in prioritizing funding and resources for further research. Especially in this work, this list guided the deployment of environmental good practices to be selected and analyzed based on the context and resource required.

Table 2 - Technological solutions and practices identified as research priorities (Continues...)

\begin{tabular}{|c|c|c|}
\hline \multirow{2}{*}{ Technological Solutions and Practices } & \multicolumn{2}{|c|}{$\begin{array}{l}\text { Research } \\
\text { Priority }\end{array}$} \\
\hline & $\begin{array}{c}\text { I\&VI } \\
(\%)\end{array}$ & $\begin{array}{l}\text { PA } \\
(\%)\end{array}$ \\
\hline \multicolumn{3}{|l|}{ Resource Consumption } \\
\hline $\begin{array}{l}\text { Reduce material losses during the carrying out of services, deliveries, internal transport, } \\
\text { storage, and handling of materials on construction sites. }\end{array}$ & 100 & 58 \\
\hline $\begin{array}{l}\text { Development of materials, products and construction systems selection criterion from } \\
\text { responsible sources that include life cycle analysis information (origin, processing, use e } \\
\text { maintenance, durability e disposal) and material properties like technical performance. }\end{array}$ & 95 & 52 \\
\hline $\begin{array}{l}\text { Improvements of temporary installations with the aim of reducing potable water and } \\
\text { electric energy consumption, as also in equipment, lighting and air conditioning systems on } \\
\text { construction sites }\end{array}$ & 86 & 29 \\
\hline $\begin{array}{l}\text { Reduction of electric energy consumption during the production activities on construction } \\
\text { sites }\end{array}$ & 85 & 18 \\
\hline $\begin{array}{l}\text { Development of a supplier analysis system formalizing aspects related to federal revenues, } \\
\text { use of environmental operating licenses, social responsibility, correct use of codes and } \\
\text { standards, etc. }\end{array}$ & 85 & 39 \\
\hline Rainwater use on construction sites & 59 & 5 \\
\hline Use of alternative energy sources including renewable energy & 48 & 0 \\
\hline Greywater use on construction sites & 44 & 2 \\
\hline \multicolumn{3}{|l|}{ Emissions and Solid Waste } \\
\hline $\begin{array}{l}\text { Control of generation, quantification, separation, storage and disposal of construction waste } \\
\text { on construction sites including Take-back scheme (return of waste products to } \\
\text { manufacturers) }\end{array}$ & 97 & 39 \\
\hline $\begin{array}{l}\text { Development of decontamination technologies and disposal solutions for dangerous } \\
\text { construction waste products such as paints, solvents, oils or other contaminated waste } \\
\text { products arising from demolition, renovations, radiological clinical repairs, industrial } \\
\text { installations among others (Class D) }\end{array}$ & 94 & 9 \\
\hline Exploitation and use of construction waste on construction sites & 91 & 23 \\
\hline $\begin{array}{l}\text { Development of technologies and economically viable applications of construction waste } \\
\text { materials that still have no recycling or recuperation solutions (Class C) }\end{array}$ & 89 & 17 \\
\hline Vegetation preservation methods in construction site areas & 85 & 33 \\
\hline $\begin{array}{l}\text { Sewage catchment and treatment systems and minimization of risks resulting from drainage } \\
\text { on construction sites }\end{array}$ & 85 & 21 \\
\hline $\begin{array}{l}\text { Identification of risks of particle emissions arising from production activities on } \\
\text { construction sites and towards the neighborhood }\end{array}$ & 85 & 21 \\
\hline $\begin{array}{l}\text { Control of groundwater levels, contamination and minimization of risks resulting from its } \\
\text { management }\end{array}$ & 85 & 21 \\
\hline Characterization, monitoring e control of particle material emissions & 74 & 12 \\
\hline
\end{tabular}

12 Thomas, N. I. R.; Costa, D. B. 
Table 2 - Technological solutions and practices identified as research priorities (continuation)

\begin{tabular}{|c|c|c|}
\hline \multirow{2}{*}{ Technological Solutions and Practices } & \multicolumn{2}{|c|}{$\begin{array}{l}\text { Research } \\
\text { Priority }\end{array}$} \\
\hline & $\begin{array}{c}\text { I\&VI } \\
(\%)\end{array}$ & $\begin{array}{l}\text { PA } \\
(\%)\end{array}$ \\
\hline \multicolumn{3}{|l|}{ Interface with External Environment } \\
\hline Reduce the erosive processes and risks of collapse/subsidence & 98 & 53 \\
\hline Characterization of sound emitting activities and plans to mitigating noise nuisance & 92 & 27 \\
\hline $\begin{array}{l}\text { Management of site access, pedestrian flow, equipment, loading and loading on } \\
\text { construction sites }\end{array}$ & 92 & 55 \\
\hline $\begin{array}{l}\text { Reduction of the site interferences with local traffic, street conservation and pavements to } \\
\text { guarantee accessibility }\end{array}$ & 91 & 47 \\
\hline $\begin{array}{l}\text { Identification of risks of particle emissions derived from production activities on the } \\
\text { neighborhood. }\end{array}$ & 88 & 30 \\
\hline Definition of demolition processes and contingency plans & 80 & 29 \\
\hline \multicolumn{3}{|l|}{ Intrinsic Quality of the Construction Site (IQ) - Health and Safety } \\
\hline Collective protection equipment against falling from heights on construction sites & 98 & 77 \\
\hline Protections against people handling equipment & 98 & 76 \\
\hline Protections against electric shocks & 98 & 76 \\
\hline Safeguards for material handling equipment & 97 & 71 \\
\hline Machine and equipment protection & 97 & 68 \\
\hline Protection of excavations & 95 & 70 \\
\hline $\begin{array}{l}\text { National certification system for Industrialized Collective Protection Equipment, similar to } \\
\text { existing certification system for Personal Protective Equipment (PPE) on construction sites }\end{array}$ & 79 & 41 \\
\hline \multicolumn{3}{|l|}{ Intrinsic Quality of the Construction Site (IQ) -Temporary Installations on Construction Sites } \\
\hline Improvements of work safety conditions inside the temporary installations & 97 & 55 \\
\hline Improvements of the health and hygiene conditions inside the temporary installations & 97 & 62 \\
\hline Reuse of temporary installation components and construction systems & 92 & 42 \\
\hline $\begin{array}{l}\text { Improvements in the lighting, ventilation and air quality conditions of temporary } \\
\text { installations }\end{array}$ & 89 & 41 \\
\hline External visual communication and signaling & 86 & 67 \\
\hline \multicolumn{3}{|l|}{ I - Important; VI - Very Important; PA - Practices Adopted } \\
\hline
\end{tabular}

Souce: Thomas, Costa e Guimarães (2013).

\section{Research method}

This work was developed using the in-depth case study strategy, which was conducted on the construction site of the new headquarters of Sinduscon-BA. This case was selected because it was the first sustainable commercial building developed in the city of Salvador and due to the opportunity to be involved from the conceptual design to handover of the project. In order to adopt best practices for a low environmental impact construction site, this study was divided into three stages:

(a) identification of best practices;

(b) selection and Implementation of best practices; and

(c) monitoring, actions and learning (Figure 1).

(d) Identification of best practices
The identification of possible best practices to be implemented was based on the literature review on the different environmental assessment methods (previously presented in Table 1), and from the findings of a survey on sustainable best practices on construction sites applied in Brazil by Guimarães (2013) and Thomas, Costa and Guimarães (2013) presented in Table 2. Also, good practices on solid waste were based on the National Environment Council (CONAMA) Resolution 307, which establishes directives, criteria and procedures for the management of waste deriving from construction in Brazil (BRASIL, 2002). Health and Safety practices were based on the NR-18 standards (Regulatory Standard -18 - Working conditions and the Environment in the Construction Industry in Brazil) (BRASIL, 2015). Air pollution practices were based on the London Council publication (COUNCILS..., 2010). 
Figure 1 - Research design

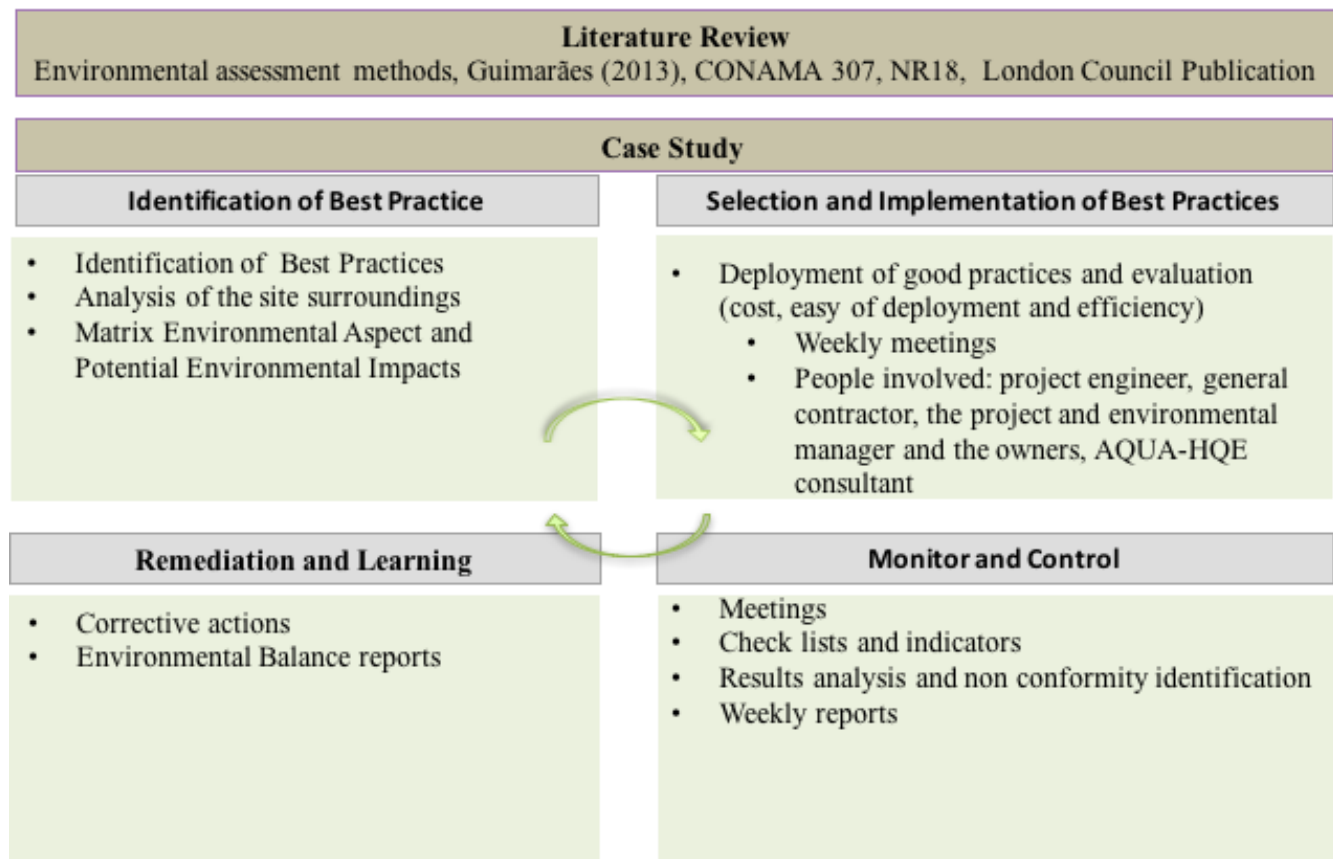

Before selecting the good practices, it was necessary to characterize the construction site in terms of its localization, construction method, ground conditions and topography, presence of water courses, water table level, presence of fauna and flora, neighborhood conditions such as nearby roads, parking, current noise levels, surrounding building types and use, such as hospitals, schools, residential housing and neighborhood habits Other characteristics were also evaluated, such as external risks, overhead electricity cables and pylons, wind direction, natural risks (flooding, landslides), local expectations of neighborhood and waste disposal areas, to mention a few.

Based on Araújo (2009), a matrix was created in an Excel sheet listing all of the construction site activities in the left hand vertical column and then, the different environmental aspects for each theme were listed in the top horizontal line (Table 3). For each environmental aspect, an analysis was made marking an " $\mathrm{X}$ " for all of the construction activities imposing a high potential risk of occurrence and an "O" for low risk of occurrence. Squares were left blank if there was no correlation between activity and environmental aspect. This way, the most important environmental aspects could be prioritized for each construction activity allowing for the selection of good practices according to each environmental aspect for the different construction activities. For each aspect, the current legislation limits were identified.

\section{Selection and implementation of best practices}

The selection of good practices and solutions to mitigate the environmental impacts of the building was carried out through weekly progress meetings during the first six months of the project with the project team, including the project engineer, general contractor, the project and environmental manager and the owners (Chamber CEO and Project Director) (Table 3). Then, monthly meetings and videoconferences with the AQUAHQE consultancy company were held to validate the selected practices. The following evaluation criteria were adopted to assist in the selection of practices and solutions:

(a) costs, including resources needed, acquisition costs, maintenance costs, supplier diversity, deadlines, ease of acquisition, transport and delivery, import dependence, lifetime guarantee of performance and disposal;

(b) efficiency, including user safety, durability, productivity, observance of deadlines and integration with other subsystems, adaptability to particularities of other construction sites; and

(c) ease of deployment, such as physical space, constructability, dependence on equipment, dependence on manpower, ease of mobility, and interference with time schedules.

The spreadsheet presented in Table 4 was developed to determine how and when to deploy each solution, the minimum conditions for 
deployment and necessary resources. From this, it was possible to compile the Best Practice Deployment Plan according to the construction schedule, setting goals and responsibilities for implementation and indicators for monitoring and control. This plan and its policies were included into the general contractor's quality management system and the specific control datasheets were elaborated and master sheets updated. The best practices were inserted into the operational and management training program and all of the construction site projects were adjusted accordingly. The implementation of the good practices was carried out through training workers at daily health and safety meetings and appointing the health and safety manager to supervise the implementation progress. In addition, a visual communication program showing good practices was provided.

Table 3 - Example of matrix of environmental aspect and potential environmental impact for new Sinduscon-BA headquarters

\begin{tabular}{|c|c|c|c|c|c|c|c|c|c|}
\hline \multirow[t]{2}{*}{ Environmental Aspect } & \multicolumn{3}{|c|}{ Consumption } & \multicolumn{3}{|c|}{ Emissions and Waste } & \multicolumn{3}{|c|}{$\begin{array}{c}\text { Interface with } \\
\text { External } \\
\text { Environment }\end{array}$} \\
\hline & $\begin{array}{l}\text { Material } \\
\text { Resource }\end{array}$ & \begin{tabular}{|c|} 
Energy \\
Efficiency
\end{tabular} & $\begin{array}{c}\text { Water } \\
\text { Management }\end{array}$ & $\begin{array}{c}\text { Solid } \\
\text { Waste }\end{array}$ & \begin{tabular}{|c|} 
Air \\
Pollution
\end{tabular} & $\begin{array}{c}\text { Water } \\
\text { Pollution }\end{array}$ & $\begin{array}{c}\text { Urban } \\
\text { Quality }\end{array}$ & Noise & \begin{tabular}{|c|} 
Visual \\
Pollution
\end{tabular} \\
\hline \multicolumn{10}{|l|}{ Preliminary Works } \\
\hline$\overline{\text { Demolition }}$ & & $\bar{X}$ & $\bar{X}$ & $\bar{X}$ & $\bar{X}$ & $\bar{X}$ & $\bar{X}$ & $\bar{X}$ & $\bar{X}$ \\
\hline Land Cleaning & & & $X$ & $\mathrm{X}$ & $\mathrm{X}$ & $\mathrm{X}$ & $\mathrm{X}$ & $\mathrm{X}$ & $\mathrm{X}$ \\
\hline Temporary Installation & $\mathrm{X}$ & $X$ & $X$ & $\mathrm{X}$ & $\mathrm{X}$ & & $\mathrm{X}$ & $\mathrm{X}$ & $\mathrm{X}$ \\
\hline $\begin{array}{l}\text { Temporary electrical and } \\
\text { water installation }\end{array}$ & & $\mathrm{X}$ & $\mathrm{X}$ & & & $\mathrm{X}$ & $\mathrm{X}$ & & $\mathrm{X}$ \\
\hline
\end{tabular}

Source: based on Araújo (2009).

Table 4 - Evaluation of the implementation of good practices

\begin{tabular}{|c|c|c|c|c|c|c|c|c|c|}
\hline $\begin{array}{l}\text { Good } \\
\text { Practices }\end{array}$ & $\begin{array}{l}\text { How to } \\
\text { implement the } \\
\text { Good Practice }\end{array}$ & Responsible & $\begin{array}{l}\text { Resource } \\
\text { needed }\end{array}$ & $\begin{array}{l}\text { Phase for } \\
\text { Application }\end{array}$ & $\dot{\tilde{e}}$ & 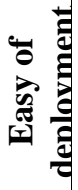 & 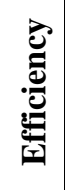 & 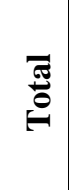 & Z \\
\hline \multicolumn{10}{|c|}{$\begin{array}{l}\text { Reduce materials losses during the carrying out of services, deliveries, internal transport, storage, and } \\
\text { handling of materials on construction sites. }\end{array}$} \\
\hline \multirow{3}{*}{$\begin{array}{l}\text { Design } \\
\text { compatibilities } \\
\text { through BIM }\end{array}$} & $\begin{array}{l}\text { BIM Training } \\
\text { sessions }\end{array}$ & $\begin{array}{l}\text { Design } \\
\text { Coordinator }\end{array}$ & $\begin{array}{l}\text { Time, } \\
\text { space, } \\
\text { people, } \\
\text { money }\end{array}$ & Program & 3 & 2 & 3 & 8 & $\mathrm{~N}$ \\
\hline & $\begin{array}{l}\text { Meeting for } \\
\text { design } \\
\text { compatibilities }\end{array}$ & $\begin{array}{l}\text { Design } \\
\text { Coordinator }\end{array}$ & & Design & 0 & 3 & 3 & 6 & $\mathrm{Y}$ \\
\hline & $\begin{array}{l}\text { Use of BIM- } \\
\text { REVIT }\end{array}$ & $\begin{array}{l}\text { Design } \\
\text { Coordinator }\end{array}$ & REVIT & Design & 3 & 1 & 3 & 7 & $\mathrm{~N}$ \\
\hline \multirow{3}{*}{$\begin{array}{l}\text { Materials } \\
\text { identified in } \\
\text { the warehouse }\end{array}$} & $\begin{array}{l}\text { Waste } \\
\text { management } \\
\text { plan }\end{array}$ & $\begin{array}{l}\text { Field } \\
\text { Engineer }\end{array}$ & Consultant & Execution & 1 & 1 & 3 & 5 & $\mathrm{Y}$ \\
\hline & $\begin{array}{l}\text { Training } \\
\text { sessions for } \\
\text { implementation } \\
\text { of waste } \\
\text { management }\end{array}$ & $\begin{array}{l}\text { Field } \\
\text { Engineer }\end{array}$ & Consultant & Execution & 1 & 1 & 3 & 5 & $\mathrm{Y}$ \\
\hline & Supply plan & $\begin{array}{l}\text { Field } \\
\text { Engineer }\end{array}$ & & Execution & 0 & 2 & 3 & 5 & $\mathrm{Y}$ \\
\hline
\end{tabular}




\section{Monitoring, action and learning}

To monitor the implementation process, an operational checklist was developed aimed at assessing the main good practices implemented for each aspect - resource consumption, solid waste, emissions, temporary facilities, health and safety and outdoor quality. It is important to note that despite the effort to be comprehensive in the selection of the practices, due to the characteristics of the project, a limited number of practices were implemented.
Checklist criterion was evaluated via a $0-1$ Scale (1 for compliance and 0 for noncompliance). The checklist was applied on a weekly basis for 13 weeks to ensure effective implementation of practices. From the checklist, 7 indicators were calculated, allowing for a quantitative analysis and definition of actions for continuous improvement, using previously raised indicators as a basis of comparison. Table 5 shows the indicators, the main good practices evaluated in the case study and the formula for each indicator.

Table 5 - Indicators and good practices (Continues...)

\begin{tabular}{|c|c|c|}
\hline Indicator & Good Practice Evaluated & Formula \\
\hline $\begin{array}{l}\text { Material, } \\
\text { Water and } \\
\text { Energy } \\
\text { Consumption } \\
\text { Index }\end{array}$ & $\begin{array}{l}\text { 1. Correct storage of materials } \\
\text { 2. Materials identified in the warehouse } \\
\text { 3. Dissemination of monthly control of } \\
\text { water consumption } \\
\text { 4. Daily shutdown of hydraulic devices } \\
\text { 5. Dissemination of monthly control of } \\
\text { energy bill } \\
\text { 6. Daily power disconnection of electrical } \\
\text { devices }\end{array}$ & $\frac{\Sigma \text { Consumption items completed } x 100}{\Sigma \text { Consumption items evaluated }}$ \\
\hline $\begin{array}{l}\text { Solid Waste } \\
\text { Index }\end{array}$ & $\begin{array}{l}\text { 1. Segregation of aggregates in the correct } \\
\text { location } \\
\text { 2. No mixed waste in disposal drums } \\
\text { 3. Conduits and material remains in correct } \\
\text { boxes } \\
\text { 4. Correct waste disposal with transport, } \\
\text { and final destination tracking and } \\
\text { control } \\
\text { 5. Separation of hazardous waste and } \\
\text { storage in confined area with protected } \\
\text { floor }\end{array}$ & $\frac{\Sigma \text { Waste items completed } x 100}{\Sigma \text { Waste items evaluated }}$ \\
\hline $\begin{array}{l}\text { Water, Soil } \\
\text { and Air } \\
\text { Pollution } \\
\text { Index }\end{array}$ & $\begin{array}{l}\text { 1. Use of circular saw and bench with } \\
\text { waste collection } \\
\text { 2. Wetting of areas during production } \\
\text { activities and when sweeping } \\
\text { 3. Wetting of materials when cutting with } \\
\text { circular saw } \\
\text { 4. Use of plastic construction safety nets } \\
\text { 5. Effluent control during concreting and } \\
\text { other production activities }\end{array}$ & $\frac{\Sigma \text { Pollution items completed } x 100}{\Sigma \text { Pollution items evaluated }}$ \\
\hline $\begin{array}{l}\text { Temporary } \\
\text { Facilities } \\
\text { Index }\end{array}$ & $\begin{array}{l}\text { 1. Visual communication signs in good } \\
\text { condition and correctly located on } \\
\text { jobsite } \\
\text { 2. Use and respect of construction site } \\
\text { project } \\
\text { 3. Daily washing, sanitation and } \\
\text { fumigation of internal areas, cloakroom } \\
\text { and dining areas } \\
\text { 4. Cleaning, organizing and sweeping of } \\
\text { internal areas } \\
\text { 5. Tools in specific boxes } \\
\text { 6. Nuts and bolts in the boxes }\end{array}$ & $\frac{\Sigma T . \text { Facility items completed } x 100}{\Sigma T . \text { Facility items evaluated }}$ \\
\hline
\end{tabular}


Table 5 - Indicators and good practices (continuation)

\begin{tabular}{|c|c|c|}
\hline Indicator & Good Practice Evaluated & Formula \\
\hline $\begin{array}{l}\text { Health and } \\
\text { Safety Index }\end{array}$ & $\begin{array}{l}\text { 1. Use of Individual Safety Equipment: } \\
\text { hearing protectors, helmet, footwear, } \\
\text { glasses, safety strap } \\
\text { 2. Use of delimitation of areas } \\
\text { 3. Guardrails in good condition } \\
\text { 4. Rack and pinion elevators operated by } \\
\text { qualified professional } \\
\text { 5. Use of trays and safety protection } \\
\text { screens against falls } \\
\text { 6. Suspended scaffolding correctly used }\end{array}$ & $\frac{\sum \text { H.Safety items completed } x 100}{\sum \text { H.Safety items evaluated }}$ \\
\hline $\begin{array}{l}\text { Outdoor } \\
\text { Quality Index }\end{array}$ & $\begin{array}{l}\text { 1. Access and material flow management - } \\
\text { Isolation of loading and unloading areas } \\
\text { and Obedience of loading and unloading } \\
\text { times } \\
\text { 2. Maintenance and cleaning of the } \\
\text { surroundings - routine cleaning around } \\
\text { construction site with daily sweeping of } \\
\text { the pavements and Use of canvas during } \\
\text { concrete discharge } \\
\text { 3. Good Neighbor Relationship - use of } \\
\text { signs on jobsite facade with e-mail for } \\
\text { complaints and Book of occurrences in } \\
\text { the jobsite entrance } \\
\text { 4. Noise pollution - Definition of strategic } \\
\text { locations for noisy equipment } \\
\text { 5. Visual pollution - The fences are well } \\
\text { maintained and around the material } \\
\text { storage deposits, and other obstacles } \\
\text { belonging to jobsite }\end{array}$ & $\frac{\Sigma \text { O.Quality items completed } x 100}{\Sigma \text { O.Quality items evaluated }}$ \\
\hline $\begin{array}{l}\text { Low-impact } \\
\text { Environmenta } \\
1 \text { Good } \\
\text { Practice Index }\end{array}$ & Overall Evaluation & $\frac{\sum \text { Items completed } x 100}{\sum \text { All items evaluated }}$ \\
\hline
\end{tabular}

\section{Results and discussion}

\section{Sinduscon-BA project description}

The Sinduscon-BA Headquarters is located in the city of Salvador-Bahia-Brazil and was built where the former headquarters once stood. The 10-story commercial building occupies an area of 594.70 $\mathrm{m}^{2}$ with a built area of $2449.06 \mathrm{~m}^{2}$, consisting of 5 office floors, an auditorium, a flexible corporate office lounge with meeting rooms for seminars, lectures and events, a roof top with garden and 2 floors for car parking. The construction process lasted 16 months, from July 2012 to November 2013. The building was built with a reinforced and pre-stressed concrete structural system, double concrete block cavity walls and steel column foundations with reinforced concrete blocks. The external ventilated facades were composed of aluminum composites and high performance glass panels.

The Sinduscon-BA new headquarters was built under the AQUA-HQE sustainability certification criteria incorporating technologies and sustainable solutions throughout the design concept stage, construction stage and its operation and use stage. Sustainable building solutions include: solar panels, wind turbines, elevated floors, building management systems with real time energy monitoring, bioclimatic facades, Dali system for natural light optimization, LEDs activated by light sensors, green roofs, green walls, natural gas central air conditioning system, enthalpic wheel, $\mathrm{CO}_{2}$ control for indoor air quality, electric vehicle charging points, showers for cyclists and cycle racks, rainwater harvesting and greywater reuse, water and energy economizing gadgets and a centralized vacuum system.

The AQUA-HQE Certification for Sustainable Buildings, applied by the Vanzolini Foundation evaluates the environmental quality of a building in 14 categories. Performance in each category is classified as good (minimum acceptable level), superior (corresponding to best practices level) and excellent (based on the maximum performances found in Sustainable Developments). The building was certified in the execution phase achieving excellent performance in six categories, and good 
in two categories. Two AQUA categories are concerned with the construction phase, Category 2 - Integrated selection of Products, Systems and Construction Processes and Category 3 - Low Environmental Impact Construction Sites.

\section{Implementation, monitoring and learning of environmental practice on jobsite}

Initially, a selective deconstruction plan in order to remove the former headquarters building and guarantee optimal valorization of materials and minimization of impacts was elaborated. All electrical and air conditioning equipment, doors and window frames, railings, removable gutters, wooden floor boards, skirting boards, lamps and lighting fixtures, switches/sockets, etc. were donated to employees and NGO'S. The remaining wood was sent to a ceramic industry for heat energy generation, plastic and glass was recycled by cooperatives. The waste masonry, slabs, mortar, blocks, floors, tiles etc. went to a recycling company for the production of aggregates. $24.4 \%$ of the construction waste aggregate was used in the basement floor of the building, replacing natural aggregates thus preventing the need to extract new resources and reducing waste disposal in landfills.

From the viewpoint of consumption, a materials selection policy was adopted based on performance criteria guaranteed through appropriate quality certification, durability, life cycle concepts, distance (privileging materials produced within a $300 \mathrm{~km}$ radius) and ease of maintenance, which was monitored by a spreadsheet. $96.58 \%$ of the materials in weight were produced within $300 \mathrm{~km}$ and $100 \%$ of the materials used in the building could be recycled in other applications after service life. All wood suppliers within a $300 \mathrm{~km}$ radius with FSC or Cerflor certification, providing full chain of custody including their environmental licenses and forest management plans were identified. Only suppliers of wood and wood products (including formwork) that were able to provide this information were used. All paints, varnishes and releasing agents for formwork were VOC free. Training of the materials procurement staff and workers on respective policies was required. Directives were given to the design team in the project brief, regarding the adoption of modular coordination, pagination projects for tiles and bricks and the requirement to prioritize local materials with quality certification.

Practices to reduce energy and water consumption were implanted such as using energy and water efficient equipment and appliances, insertion of procedures for switching off gadgets as well as the energy and water supply at the end of each day, and monthly monitoring of energy and water consumption. These guidelines were also passed on to the subcontractors and suppliers of equipment. Figure 2 presents water and energy consumption indicators, showing that despite the high progress of construction from June to September 2013, the relation between water and energy consumption and Man-hour maintained quite stable. These consumption practices were implemented at the beginning and therefore inserted as a policy in the contractor's management system.

Figure 2 - Water and Energy consumption per man-hour along the project
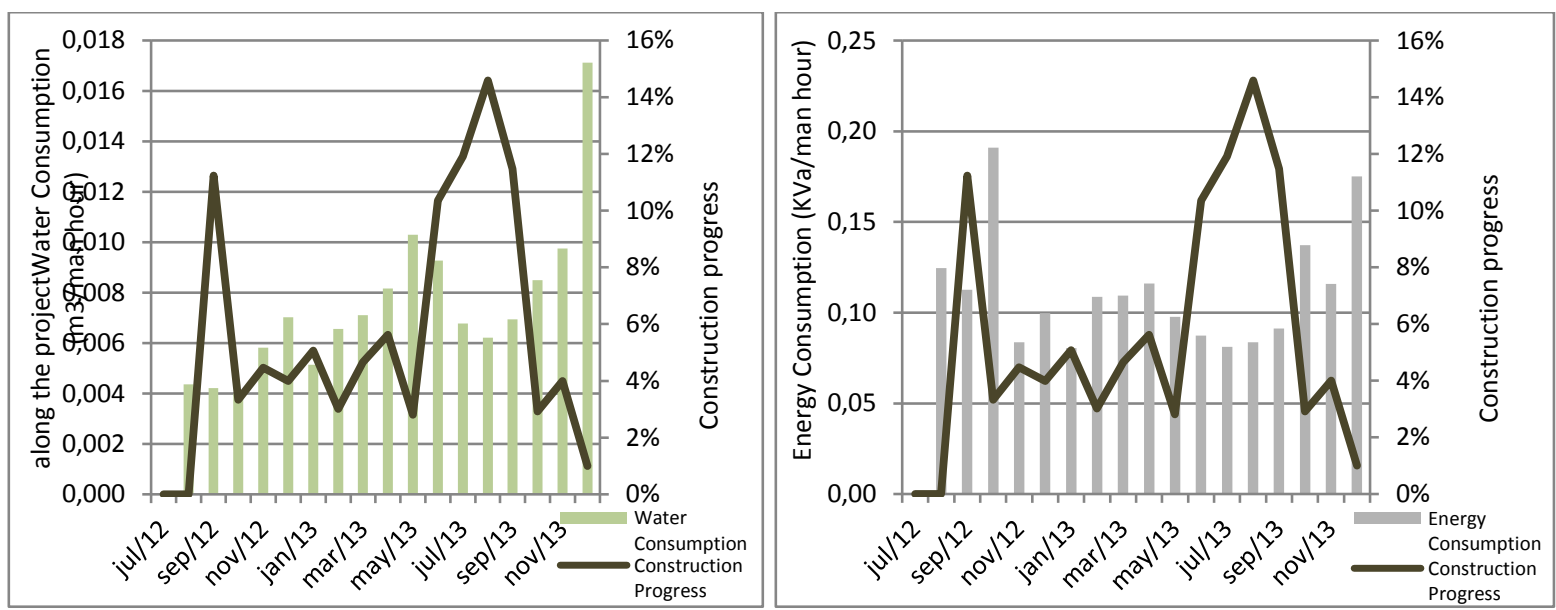

18 Thomas, N. I. R.; Costa, D. B. 
A waste management plan was implemented. A spreadsheet was developed, discriminating waste type and quantity for each month allowing comparisons between previously established indicators. The first targets for waste generation were set based on the estimated volume of waste generated per construction activity and material type after having considered and implemented actions to minimize waste production. Each month, new reduced production targets were created based on the results from previous months. Costs with transportation and disposal as well as income with sales were also monitored to determine the critical waste type in terms of quantity and cost using an $\mathrm{ABC}$ curve. Another spreadsheet was compiled to control the waste generation and valorization. Results showed that $83.7 \%$ of all waste generated during construction was reused or valorized as raw material in the studied project.

Best practices aimed at controlling particle emissions and minimizing their risks were implanted such as using water during earthworks, irrigation of soils, wetting objects while sweeping and before cutting with a saw to avoid dust. Large facade safety nets were attached to each face of the construction site, to protect the neighbors from falling debris and dust. Groundwater levels were controlled, surface runoff and rainwater collection with adequate drainage systems were implanted with the provision of effluent treatment systems before directing it to the public network, thus avoiding soil and water pollution and minimizing risks of contamination on the construction site. During unloading of materials and concrete, plastic sheets were placed on roads under the truck to collect the remains of materials allowing for its reuse, or referral to the effluent box, avoiding obstruction of public drainage systems. Greywater was reused, such as water from the mortar mixer and from cleansing of equipment and concreting. Water from sinks was reused in the urinals.

Training of workers conducted by the health and safety manager occurred on a daily basis in order to ensure the implementation of the practices. Topics included health and safety programs, environmental principals, and rational use of water, energy, waste material, waste management and risk prevention. A digital inclusion program was offered to the workers, families and the neighborhood car valets, with an Employee of the Month Program awarding one worker per month for exemplary behavior based on set criteria. Regular jobsite inspections were performed by the health and safety manager to ensure effective implementation of good practices. Integration trainings were carried out with new teams and subcontractors.

Temporary facility designs were developed for each construction phase, defining strategic positions for noisy equipment and acoustic treatments thereby reducing the impacts on the neighborhood. Delivery times were agreed with neighbors banning noisy work at weekends and before 8 am and after $6 \mathrm{pm}$ on week days. Sound levels were monitored during concreting as well as ensuring that equipment was in good condition, favoring equipment with lower noise and vibration emissions. The production of onsite mortars was minimized, using prefabricated and industrialized materials. Site access and pedestrian flows were managed with daily cleaning and maintenance of roads and sidewalks. A good neighborhood policy was implemented promoting transparency through signs with contact details for complaints and suggestions. Neighborhood buildings were regularly visited. Notification letters were sent out 48 hours prior the concreting and other noisy activities. Complaints were registered and monitored with corrective actions implemented.

Table 6 shows that the critical period of the project concerned to claims was in November and December 2012, during superstructure works with a total of 7 claims related to neighborhood house damages, cleanness and particulate matter emissions.

Table 7 shows the findings for the monitoring of low impact environmental good practices from July to October 2013, according to the indicators, good practices and criteria aforementioned at Table 2.

Table 6 - Neighborhood feedback during the construction

\begin{tabular}{l|c|c|c|c|c|c|c|c}
\hline $\begin{array}{c}\text { Neighbourhood positive } \\
\text { feedback or claims }\end{array}$ & Nov/12 & Dec/12 & Jan/13 & Feb/13 & Mar/13 & Apr/13 & May/13 & Total \\
\hline Positive feedback & 1 & 1 & & & & & 1 & $\mathbf{3}$ \\
Noisy claims & & 1 & & & & 1 & & $\mathbf{1}$ \\
Particulate emission claims & 2 & 2 & & 1 & 1 & & & $\mathbf{6}$ \\
Neighbour house damages & 1 & 1 & 1 & & & & & $\mathbf{3}$ \\
Dirty claims &
\end{tabular}


Table 7 - Monitoring of environmental good practice indicators per month

\begin{tabular}{l|l|l|l|l|l}
\hline \multicolumn{1}{c|}{ Indicators } & Jul/13 & Aug/13 & Sep/13 & Oct/13 & Average \\
\hline Material, Water and Energy Consumption Index & $71 \%$ & $54 \%$ & $89 \%$ & $50 \%$ & $\mathbf{6 6 \%}$ \\
Solid Waste Index & $80 \%$ & $80 \%$ & $73 \%$ & $80 \%$ & $\mathbf{7 8 \%}$ \\
Water, Soil and Air Pollution Index & $80 \%$ & $85 \%$ & $93 \%$ & $60 \%$ & $\mathbf{8 0 \%}$ \\
Temporary Facilities Index & $73 \%$ & $86 \%$ & $67 \%$ & $91 \%$ & $\mathbf{7 9 \%}$ \\
Health and Safety Index & $75 \%$ & $86 \%$ & $71 \%$ & $79 \%$ & $\mathbf{7 8 \%}$ \\
Outdoor Quality Index & $78 \%$ & $84 \%$ & $89 \%$ & $89 \%$ & $\mathbf{8 5 \%}$ \\
Low-impact Environmental Good Practice Index & $\mathbf{7 6 \%}$ & $\mathbf{7 9 \%}$ & $\mathbf{8 0 \%}$ & $\mathbf{7 5 \%}$ & $\mathbf{7 8 \%}$ \\
\hline
\end{tabular}

Difficulty in meeting the consumption items criteria was found. Despite the training of workers on the rational resource use, the dissemination of these onto workers was not a routine. Often the storage of materials was also not appropriate. From the material purchase viewpoint, the project team faced difficulties in finding material manufacturers near to the city of Salvador, such as high flag ash Portland Cement, ceramic tiles, aluminum composites and glass. It is therefore necessary to incentivize local industries.

Due to a structured waste program under an external consultancy, almost $80 \%$ of the practices were systematically implemented during the study. One of the difficulties was concerned with plaster waste, as despite the legal requirement set out by the CONAMA Resolution N. 307 (BRASIL, 2002), there is to date, no industry to receive plaster waste in Salvador, so it was sent to a dangerous waste landfill. Another important consideration is that waste management requires continual monitoring and training in order to ensure correct segregation.

Often waste was found mixed together therefore requiring more bins located in strategic work areas to promote reuse within the jobsite. At times, subcontractors showed a resistance in adapting to the contractors' sustainable construction policies. Even with daily training on waste management and other practices emphasizing importance, the construction site had some difficulties in making the workers participate, due to the high employee turnover and the fact that the subcontractor employees would only be working on the site for a predetermined time. Meetings were held with the subcontractor managers to enforce employee commitment, thus confirming the need to determine measures and include previously agreed contractual terms guaranteeing adherence to best practices and project policies when hiring subcontractors.

Concerning pollution, there was an evolution in the implementation of good practices until September 2013 after which there was a drop. The recurrent problems identified were the lack of maintenance and often complete removal of the construction safety nets attached to the facade. The wind destroyed these quickly and so, there were often periods completely without them. In addition, the production team did not always wet areas during the production activities and when sweeping.

Despite the intense and greater concern with health and safety training enforced by the Brazilian Regulatory NR 18 standards (BRASIL, 2015), this indicator showed a fall in September 2013 for different reasons, such as not using individual safety equipment (Hearing Protectors, Footwear, Glasses) and also equipment for delimitation of areas and guardrails in bad conditions. In terms of the Low- impact Environmental Good Practice Index (LIEGPI), performance increase was noticed, despite a drop in October 2013, which might be attributed to the amount of work in progress in the last two months of the construction and the focus of the project team on meeting the construction schedule rather than the environmental issues.

\section{Recommendations for the adoption of environmental practice on construction site}

The construction site is a dynamic space in which several changes are made during the execution phase. Therefore, solutions and potential barriers should be forecasted before the construction phase or major activities start. The implementation of low environmental impact construction sites requires a set of guidelines, as discussed below.

\section{Considering site sustainability in the design phase}

During the project briefing stage, all designers should be given the necessary recommendations regarding the sustainability attributes to be adopted also considering the construction phase, such as the materials policy and construction methods with the aim of minimizing waste production and promoting rational resource use. On the other hand, contractors need to share their knowledge of construction cost and quality to promote cost- 
effective sustainability (HOLLOWAY; PARRISH, 2015). These two authors state that early contractor involvement in the design phase will allow enhanced cost and sustainability feedback regarding design option.

\section{Planning the construction site}

Before starting any construction work, it is necessary to characterize and analyze the construction site, the surrounding neighborhood and the legal requirements. Then, the environmental aspects and impacts relevant to each construction activity should be identified and prioritized. The selection of the practices should consider cost, efficiency and ease of employment criteria. The selected practices should put into a Construction Site Environmental Management Plan containing a detailed plan on how and when each solution should be implemented, what resources are required, who will be responsible and how it will be monitored. The Main Contractors' Quality Management system can be adjusted including the data control sheets, and relevant training material.

\section{Implementing practices}

The implementation of low impact construction sites should start with the training of workers and assigning a responsible for the work to guarantee effective implementation and monitoring of the low environmental impact construction site. This responsibility can be attributed to health and safety managers or an environmental manager. Provision of a visual communication program will assist implementation as well as training of workers in short daily meeting and specific lectures, with the aid of good practice photos and posters.

\section{Hiring of subcontractors}

The responsibility of adhering to the construction site environmental management plan, policies and procedures must also be passed on to the subcontractors and inserted during negotiations and formalization of contracts. Existing management systems should be extrapolated and extended to subcontractor management systems, defining parameters for the formulation of contracts, stipulation of goals and rules regarding the reduction of losses, etc.

\section{Operational training}

To ensure the effective implementation of good practices in the construction site, it is necessary to develop operational training programs and encourage the integration of subcontractors and labor to enhance their commitment, such as: (a) training on reducing loss of material in the assignment, delivery, internal transport, storage and handling of materials on the construction site;

(b) training on procurement of materials and products, including training on criteria and purchasing policies, reverse logistics, and supplier evaluation;

(c) training on the implementation of waste management plans, ensuring separation of waste at the source to maintain the quality of waste material and its potential to be reused or valorized, and allocation of storage areas on each floor of the construction site;

(d) training on monitoring and minimizing the emission of particulates and integration of these practices as operational procedures; and

(e) training and awareness about sound pollution, methods to characterize activities that emit noise and mitigation plans.

\section{Monitoring and control}

To evaluate the effective implementation of best practices, a deployment checklist can be applied weekly generating indicators, which can also be used to motivate site workers. Spreadsheets should be developed to control and monitor all data. Weekly meetings also help enforce the effective implementation of the best practices; they should be held with the presence of the production engineer, the project manager, and health and safety manager with minutes distributed via email after the meeting for all participants. Attention should be given for producing and dissemination metrics that also measure the successful realization of design intent in order to recognize the construction phase as an important component of sustainable buildings (HOLLOWAY; PARRISH, 2015).

\section{Conclusion and recommendations}

The main theoretical contribution of this paper is the establishment of conditions, criteria, and metrics during the construction phase to evaluate the implementation process of management practices for low environmental impact construction sites, also presenting the effects of a comprehensive on-site sustainable practice program. At a practical level, the paper provides tools and recommendations for the implementation and assessment of environmental good practices on construction sites, allowing the development of a methodology elaborated based on a real case considering important requirements. 
Although this case study was based on a single construction project, the study was long and intense, involving the participation of various entities from the industry and the academia, which required a strong commitment and input from professionals from all hierarchical levels. Despite these limitations, this methodology can be used to evaluate the implementation of different best practices and provides guidance on the various levels of training and incentives for the adoption of these practices.

Through this case study, it was observed that, in order to assist in achieving sustainability on construction sites, construction site design plans should be developed, redeeming design solutions and management practices adopted for permanent buildings and exploiting them into the design of temporary facilities, with assigned technical responsibility.

In addition, the implantation of sustainable construction sites also depends on an entire supply chain that must also be engaged in achieving sustainable development, which requires a commitment from all parties involved. It is necessary to encourage enterprises to develop training programs and use local labor, training engineers and architects and creating new public policy agendas, promoting forums aimed at strengthening the link between the construction industry, academia and government.

Furthermore, incentives are required for the development of industrialized materials and technologies decentralizing factories as a whole in Brazil. Subsidies should be created in order to promote innovative technologies that are energy efficient, use resources rationally and are economically feasible. It is important to develop certification systems and other methods to ensure compliance and quality of materials, products and systems.

From this study, a methodology for adoption of low environmental impact construction sites was developed. However, further studies should be carried out for its validation. A best practices manual is under development in alignment with national and international protocols on reducing environmental impacts on construction sites.

\section{References}

ABDUL-RAHMAN, H. et al. Integrating and Ranking Sustainability Criteria for Housing. Engineering Sustainability, v. 169, n.1, p. 1-30, 2016.
ARAÚJO, I. P. S.; COSTA, D. B., MORAES, R. J. B. Identification and Characterization of Particulate Matter Concentrations at Construction Jobsites. Sustainability, v.6, n.11, p. 7666-7688, 2014.

ARAUJO, V. M. Práticas Recomendadas Para a Gestão Mais Sustentável de Canteiro de Obras. São Paulo, 2009. 228 f. Dissertação (Mestrado em Engenharia Civil) - Escola Politécnica, Universidade de São Paulo, São Paulo, 2009.

BRASIL. Ministério do Meio Ambiente. Conselho Nacional do Meio Ambiente. Resolução n. 307, julho 2002. Disponível em:

<hp://www.mma.gov.br/port/conama/res/ res02/res30702.html>. Acesso em: 12 nov. 2016.

BRASIL. Ministério do Trabalho e Emprego. NR18: condições e meio ambiente de trabalho na indústria da construção. 2015. Disponível em: <hp://trabalho.gov.br/seguranca-e-saude-notrabalho/normazacao/ normasregulamentadoras/norma-regulamentadora-n-18condicoes-e-meio-ambiente- de-trabalho-naindustria-da-construcao>. Acesso em: 15 nov. 2015.

BALLESTEROS, M. J. et al. Noise Emission Evolution on Construction Sites: measurement for controlling and assessing its impact on the people and on the environment. Building and

Environment, v. 45, n. 3, p. 711-717, 2010.

BERGE, B. The Ecology of Building Materials. $2^{\text {nd }}$. ed. Oxford: Architectural Press, 2009.

\section{BUILDING RESEARCH ESTABLISHMENT \\ ENVIRONMENTAL ASSESSMENT \\ METHODOLOGY. Europe Commercial}

Assessor Manual. London: BRE Global, 2009.

COUNCILS LONDON. Guidance Note

Construction Sites. London: Local Government: Air Quality Toolkit, 2010.

DEGANI, C. M. Sistemas de Gestão Ambiental em Empresas Construtoras de Edifícios. São Paulo, 2003. Dissertação (Mestrado em Engenharia Civil) - Escola Politécnica, Universidade de São Paulo, 2003.

DING, G. K. C. Sustainable Construction: the role of environmental assessment tools. Journal of Environmental Management, v. 86, n.3, p. 451464, 2008.

FUNDAÇÃO VANZOLINI. Referencial Técnico de Certificação: edifícios habitacionais, Processo AQUA. São Paulo: Fundação Vanzolini, 2010. 
GANGOLELLS, M, et al. A Methodology for Predicting the Severity of Environmental impaCts Related to the Construction Process of Residential Buildings. Building and Environment, v.44, n.3, p 558-571, 2009.

GANGOLELLS, M. et al. Model for Enhancing Integrated Identification, Assessment and Operational Control of On-Site Environmental Impacts and Health and Safety Risks in Construction Firms. Journal of Construction Engineering and Management, v. 139, n. 2, p 138-47, 2013.

GANGOLELLS, M. et al. Analysis of the Implementation of Effective Waste Management Practices in Construction Projects and Sites.

Resources, Conservation and Recycling, v. 93, n. 12, pp 99-111, 2014.

GANGOLELLS, M. et al. Assessing Concerns of Interested Parties When Predicting the Significance of Environmental Impacts Related to the Construction Process of Residential Buildings. Building and Environment, v. 46, n. 5, p. 10231037, 2011.

GEHLEN, J. Construção da Sustentabilidade em Canteiros de Obras. Brasília, 2008. Dissertação (Mestrado em Engenharia Civil) - Escola de Engenharia, Universidade de Brasília, Brasília, 2008.

\section{GUIMARÃES, M. S. O. Diretrizes Para} Desenvolvimento de Canteiro de Obras Habitacional de Baixo Impacto Ambiental. Salvador, 2013. Dissertação (Mestrado em Engenharia Ambiental Urbana) - Escola Politécnica, Universidade Federal da Bahia, Salvador, 2013.

HINZE, J.; GODFREY, R.; SULLIVAN, J. Integration of Construction Worker Safety and Heath in Assessment of Sustainable Construction. Journal of Construction Engineering and Management, v. 13, n. 6, p. 594-600, 2013.

HOLLOWAY, S.; PARRISH, K. The Contractor's Role in the Sustainable Industry: Institution of Civil Engineers. Engineering Sustainability, v. 168, n. 2, p. 53-60, 2015.

IRIZARRY, J. et al. The Development of Sustainable: construction planning system. Journal of Information Technology in Construction, v. 17, n. 1, p. 1874-4753, 2012.

JOHN, V. M.; PRADO, R. T. A . Selo Casa Azul: boas práticas para habitação mais sustentável. São Paulo: Páginas \& Letras, 2010.
KHASREEN, M. M.; BANFILL, P. F. G.; MENZIES, G. F. Life-Cycle Assessment and the Environmental Impact of Buildings: a review. Sustainability, v. 1, n. 3, p. 674-701, 2009.

KILBERT, C. J. Sustainable Construction: green building design and deliver. London: John Wiley and Sons, 2005.

KIM, S. S. et al. Development of a Housing Performance Evaluation Model for Multi-Family Residential Buildings in Korea. Building and Environment, v. 40, n. 8, p. 1103-1116, 2005.

KUKADIA, V.; UPTON, S.; HALL, D. Control of Dust From Construction and Demolition Activities. London: BRE, DTI, UK, 2003.

NETREGS ENVIRONMENT AGENCY UK. Presents a Good Practice Guide and How to Abide to Environmental Laws. 2012. Disponível em: 〈http://www.netregs.gov.uk>. Acceso em: 15 nov. 2012.

PROBERT, A. J. et al. Accounting for the Life Cycle Carbon Emissions of New Dwellings in the UK. In: INTERNATIONAL CONFERENCE ON NONCONVENTIONAL MATERIALS AND TECHNOLOGIES, 12., Cairo, 2010. Proceedings... Cairo, 2010.

PULASKI, M. H. (Ed.). Field Guide for Sustainable Construction. Washington: Pentagon Renovation and Construction Program Office, 2004.

RAO, A.; JHA, N. K.; MISRA, S. Use of Aggregates From Recycled Construction and Demolition Waste in Concrete. Resources, Conservation and Recycling, v. 50, n. 1, p. 71-81, 2007.

TAM, V. W. Y. et al. Environmental Performance Measurement Indicators in Construction. Building and Environment, v. 41, n. 2, p. 164-173, 2006.

THOMAS, N. I. R.; COSTA, D. B.; GUIMARÃES, M. S. O. Identification of the Primary Needs for Sustainability and Improvements in Working Conditions on Construction Sites. In: CIB WORLD CONGRESS, Brisbane, 2013, Proceedings... Brisbane, 2013.

UNITED STATES GREEN BUILDING COUNCIL. LEED 2009 for New Buildings and Major Renovations Rating System. San Francisco, 2009.

UNITED STATES ENVIRONMENTAL PROTECTION AGENCY. Particle Pollution and Your Health. 2006. 


\section{Acknowledgements}

We are grateful to the Cantechis Project (Technologies for Sustainable Construction on Social Housing Jobsites), the Ministry of Science, Technology and Innovation, through FINEP
(Financiadora de Estudos e Projetos) and $\mathrm{CNPq}$ (Conselho Nacional de Desenvolvimento Científico e Tecnológico) and the Construction Chamber for the state of Bahia (Sinduscon-BA), Brazil, who collectively funded this project.

Natasha Ilse Rothbucher Thomas

Faculty of Health and Life Sciences, School of Pharmacy | De Montfort University | The Gateway, Leicester LE1 9BH, Leicester, United Kingdom | Tel.: +44 (0) 1162306443 | E-mail: nashatasha@hotmail.com

\section{Dayana Bastos Costa}

Departamento de Construção e Estruturas, Escola Politécnica | Universidade Federal da Bahia | Av. Aristides Novis, 2, Federação | Salvador - BA - Brasil | CEP 40210-630 | Tel.: (71) 3283-9731 | E-mail: dayanabcosta@ufba.br

\section{Revista Ambiente Construído}

Associação Nacional de Tecnologia do Ambiente Construído

Av. Osvaldo Aranha, $99-3^{\circ}$ andar, Centro

Porto Alegre - RS - Brasil

CEP $90035-190$

Telefone: +55 (51) 3308-4084

Fax: +55 (51) 3308-4054

www.seer.ufrgs.br/ambienteconstruido

E-mail: ambienteconstruido@ufrgs.br

24 Thomas, N. I. R.; Costa, D. B. 